\title{
A new species of Hisonotus (Siluriformes, Loricariidae) from rio São Francisco basin, Brazil
}

\author{
Fábio F. Roxo', Gabriel S. C. Silva', Claudio Oliveira' \\ I Universidade Estadual Paulista, Departamento de Morfologia, Laboratório de Biologia e Genética de Peixes, \\ Rubiäo Júnior s/n, 18618970 Botucatu, São Paulo State, Brazil \\ Corresponding author: Fábio F. Roxo (roxoff@hotmail.com.br)
}

Academic editor: N. Bogutskaya | Received 14 January 2015 | Accepted 16 April 2015 | Published 21 April 2015

http://zoobank.org/154FEB27-179B-4DE0-B2B4-5BF7A61D44D3

Citation: Roxo FF, Silva GSC, Oliveira C (2015) A new species of Hisonotus (Siluriformes, Loricariidae) from rio São Francisco basin, Brazil. ZooKeys 498: 127-143. doi: 10.3897/zookeys.498.6896

\begin{abstract}
A new species of Hisonotus is described from the rio São Francisco basin. The new species can be distinguished from congeners by having (1) a unique coloration pattern of caudal fin with one black spot extending from its origin to the ventral lobe and two dark spots at the end of the lobe's rays; (2) odontodes forming longitudinally aligned rows on head and trunk; (3) a functional $V$-shaped spinelet; (4) a single rostral plate at the tip of the snout; (5) by lacking contrasting dark geometric spots on the anterodorsal region of the body; (6) a lower caudal-peduncle depth; and (7) lower counts of the lateral median plates and (8) higher premaxillary and dentary teeth. The new species is the second described species of the genus Hisonotus in the rio São Francisco basin. It was found inhabiting the marginal vegetation of the rio São Francisco and three of its tributary, rio das Velhas, rio Paraopeba and rio Formoso.
\end{abstract}

\section{Keywords}

Cascudinhos, Fresh-Water, Minas Gerais State, Neotropical Fish, Otothyrinae

\section{Introduction}

Loricariidae is one of the largest and most diverse families of Neotropical freshwater fish with about 900 valid species (Eschmeyer and Fong 2014). The loricariids are subdivided into seven subfamilies: Delturinae, Hypoptopomatinae, Hypostominae, Lithogeninae, Loricariinae, Neoplecostominae, and Otothyrinae (Armbruster 2004; Reis et al. 2006; Chiachio et al. 2008; Roxo et al. 2014a). Currently, Otothyrinae

Copyright Fábio F. Roxo et al. This is an open access article distributed under the terms of the Creative Commons Attribution License (CC BY 4.0), which permits unrestricted use, distribution, and reproduction in any medium, provided the original author and source are credited. 
(sensu Chiachio et al. 2008 and Roxo et al. 2014a) is composed of about 100 valid species classified in twelve genera (Eschmeyer 2014).

Within the Otothyrinae, the genus Hisonotus Eigenmann \& Eigenmann, 1889 (type species $H$. notatus Eigenmann \& Eigenmann, 1889) was resurrected by Schaefer (1998) with the following combination of characters: snout plates in the anterior portion of the nostril reduced or absent, the rostrum having enlarged odontodes, and the lateral rostral margin composed of thickened plates. However, Britski and Garavello (2007) considered the rostrum with enlarged odontodes as a character very polymorphic and present in several other genera and species of Otothyrinae, as in species of Parotocinclus Eigenmann \& Eigenmann, 1889. Furthermore, Britski and Garavello (2007) suggested that the other two characters are not satisfactory to define the genus Hisonotus.

Currently, Hisonotus contains 34 valid species, 19 of which were described in the past decade (Eschmeyer 2014), representing an increase of $127 \%$ of the diversity of this genus. Herein, we add a new species to the genus Hisonotus found during recent collection expeditions to the rio São Francisco basin. This is the second species of the genus described from this hydrographic system.

\section{Material and methods}

Measurements and counts were taken from the left side of the fish, and were made from point to point to the nearest $0.1 \mathrm{~mm}$ with a digital caliper. Abbreviations used in the text and the measurements followed Carvalho and Reis (2009). Specimens were cleared and double stained (c\&s) according to the method of Taylor and Van Dyke (1985). Vertebral counts also include the five vertebrae that comprise the Weberian apparatus and the compound caudal centrum (PU1 + U1) as one element. Dorsalfin ray counts include the spinelet as the first unbranched ray. Institutional acronyms follow Fricke and Eschmeyer (2014). Specimens are deposited at the LBP, Laboratório de Biologia e Genética de Peixes, Universidade Estadual Paulista, Botucatu; MZUSP, Museu de Zoologia, Universidade de São Paulo, São Paulo. Zoological nomenclature follows the International Code of Zoological Nomenclature (International Commission on Zoological Nomenclature 1999).

\section{Results}

\section{Hisonotus vespuccii sp. n.}

http://zoobank.org/CD9657F5-3F02-4B32-BF89-24AF86020201

Figure 1, 3; Table 1

Holotype. MZUSP 115274 (female 32.6 mm SL) Brazil, Minas Gerais State, municipality of Pirapora, rio São Francisco, $17^{\circ} 21^{\prime} 00^{\prime \prime S}, 4^{\circ} 57^{\prime} 08^{\prime \prime W}, 11$ November 2014, LE Ochoa, FF Roxo, LH Roxo, GSC Silva. 


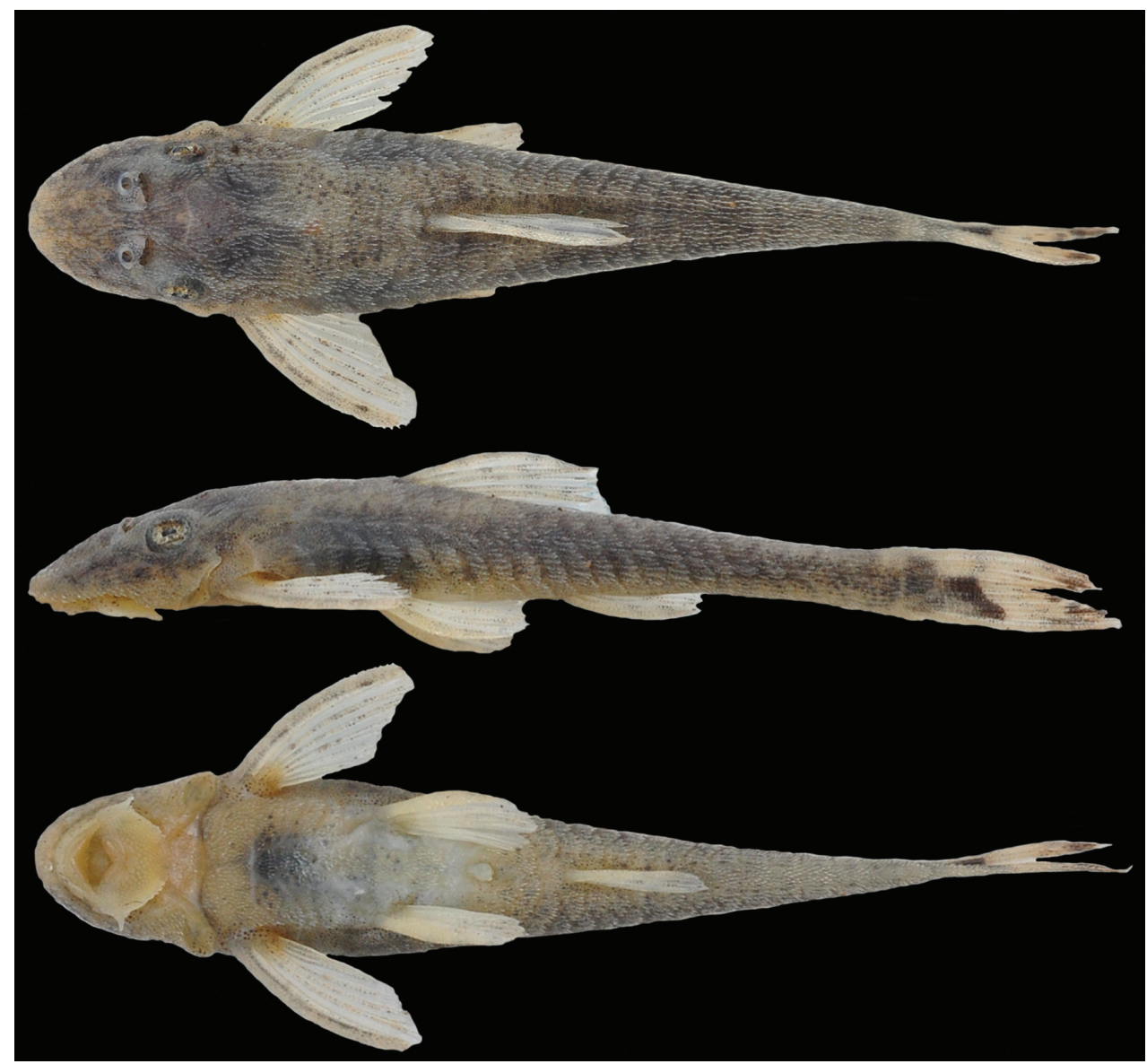

Figure I. Holotype of $H$. vespuccii, MZUSP 115274, female, $32.6 \mathrm{~mm}$ SL, from Minas Gerais State, municipality of Pirapora, rio São Francisco, $17^{\circ} 21^{\prime} 00^{\prime S}$, 4457'08"W.

Paratypes. All from Brazil, Minas Gerais State, rio São Francisco basin (249 specimens in total). LBP 8960 (4 females 32.3-35.8 mm SL, 3 males 27.0-28.2 mm

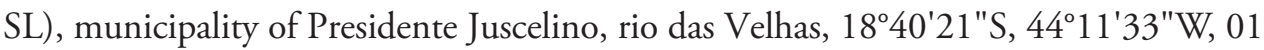
October 2009, C Oliveira, FF Roxo, GJC Silva, BF Melo. LBP 10421 (9 females 27.7$30.3 \mathrm{~mm}$ SL, 9 males 23.6-26.5 mm SL, 5 c\&s sex not determined 20.2-29.6 mm SL), municipality of Pirapora, rio São Francisco, 17²21'00"S, 4457'08"W, 15 July 2010, JA Senhorini, M Mehanna. LBP 19491 (9 females 19.9-32.4 mm SL, 12 males 21.1-27.9 mm SL, 1 female c\&s 32.6 mm SL, 1 male c\&s 27.7 mm SL), collected with holotype. LBP 19495 (1 female 32.6 mm SL, 1 male 28.7 mm SL), municipality of Presidente

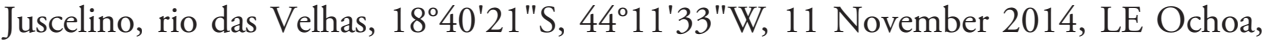
FF Roxo, LH Roxo, GSC Silva. MZUSP 39208 (5 sex not determined 23.8-30.0 mm SL), rio São Francisco, 29 November 1987, Y Sato (UHE Formoso project). MZUSP 39280, (3 sex not determined 28.4-30.2 mm SL), rio São Francisco, 20 January 1988, Y Sato (UHE Formoso project). MZUSP 39351 (33 sex not determined 16.5-34.4 
mm SL), rio São Francisco, 23 January 1988, Y Sato (UHE Formoso project). MZUSP 39446 (9 sex not determined 22.9-30.5 mm SL), rio Formoso, 08 February 1988, Y Sato (UHE Formoso project). MZUSP 39482 (1 sex not determined $24.5 \mathrm{~mm} \mathrm{SL}$ ), rio Formoso, 08 to 10 February 1988, Y Sato (UHE Formoso project). MZUSP 39511 (1 sex not determined $30.4 \mathrm{~mm} \mathrm{SL}$ ), córrego Marambaia, rio São Francisco, $09 \mathrm{Fe}-$ bruary 1988, Y Sato (UHE Formoso project). MZUSP 51507 (2 sex not determined 25.6-31.3 mm SL), municipality of Fortuna de Minas, rio Paraopeba, 13 July 1995, CBM Alves. MZUSP 57587 (110 sex not determined 20.8-33.6 mm SL), street between municipalities of Itacarambí and Manga, córrego das Missóes, 15 July 1993, RE Reis. MZUSP 57588 (7 sex not determined 20.2-24.9 mm SL), street between municipalities of Manga and Montalvânia, rio Japuré, rio São Francisco, 15 July 1993, RE Reis. MZUSP 57590 (20 sex not determined 22.8-31.4 mm SL), municipality

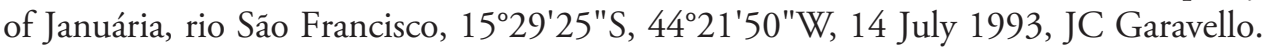
MZUSP 57591 (3 sex not determined 23.1-26.5 mm SL), street between municipalities of Manga and Montalvânia, rio Calindó, rio São Francisco, 15 July 1993, RE Reis.

Diagnosis. Hisonotus vespuccii differs from the congeners by having a unique coloration pattern of caudal fin with one black spot extending from its origin to the ventral lobe and two dark spots at the end of the lobe's rays and the following combination of character states (none is unique): odontodes forming longitudinally aligned rows (one odontode after the other, but not necessarily forming parallel series) on head and trunk; a functional $V$-shaped spinelet; the presence of a single rostral plate at tip of the snout; the lack of contrasting dark geometric spots on the anterodorsal region of the body; a low caudal peduncle (depth 6-8\% SL); few lateral median plates (21-23); and numerous premaxillary and dentary teeth (13-21 and 11-21, respectively).

Description. Counts and measurements are presented in Table 1. Maximum body size $35.7 \mathrm{~mm}$ SL. Dorsal profile of head, in lateral view, slightly convex from snout tip to margin of posterior naris; strongly convex to posterior margin of parieto-supraoccipital; and almost straight to dorsal-fin origin. Dorsal profile of trunk, in lateral view, straight and descending from dorsal-fin origin to insertion of caudal-fin. Ventral profile, in lateral view, straight from snout tip to anal-fin origin; concave and ascending to caudal-fin insertion. Greatest body depth at dorsal-fin origin (14-18\% SL). Greatest body width at cleithral region (21-25\% SL), progressively narrowing towards to both snout and caudal fin. Cross-section of body between pectoral and pelvic fins dorsally rounded and ventrally flat; cross-section of caudal peduncle ellipsoid, rounded laterally and almost flat dorsally and ventrally.

Head rounded in dorsal view; snout round and slightly pointed. Dorsal and ventral series of odontodes along anterior margin of snout completely covering its tip; odontodes larger than remaining ones on head. Odontodes on head and trunk hypertrophied and arranged in longitudinal rows. Head without conspicuous crests. Some specimens with a poor developed tuft of odontodes in posterior portion of parieto-supraoccipital. Eyes small (13-17\% HL), dorsolaterally positioned. Iris operculum present and developed. Premaxillary teeth 13-21; dentary teeth 11-21. Teeth bifid, major 


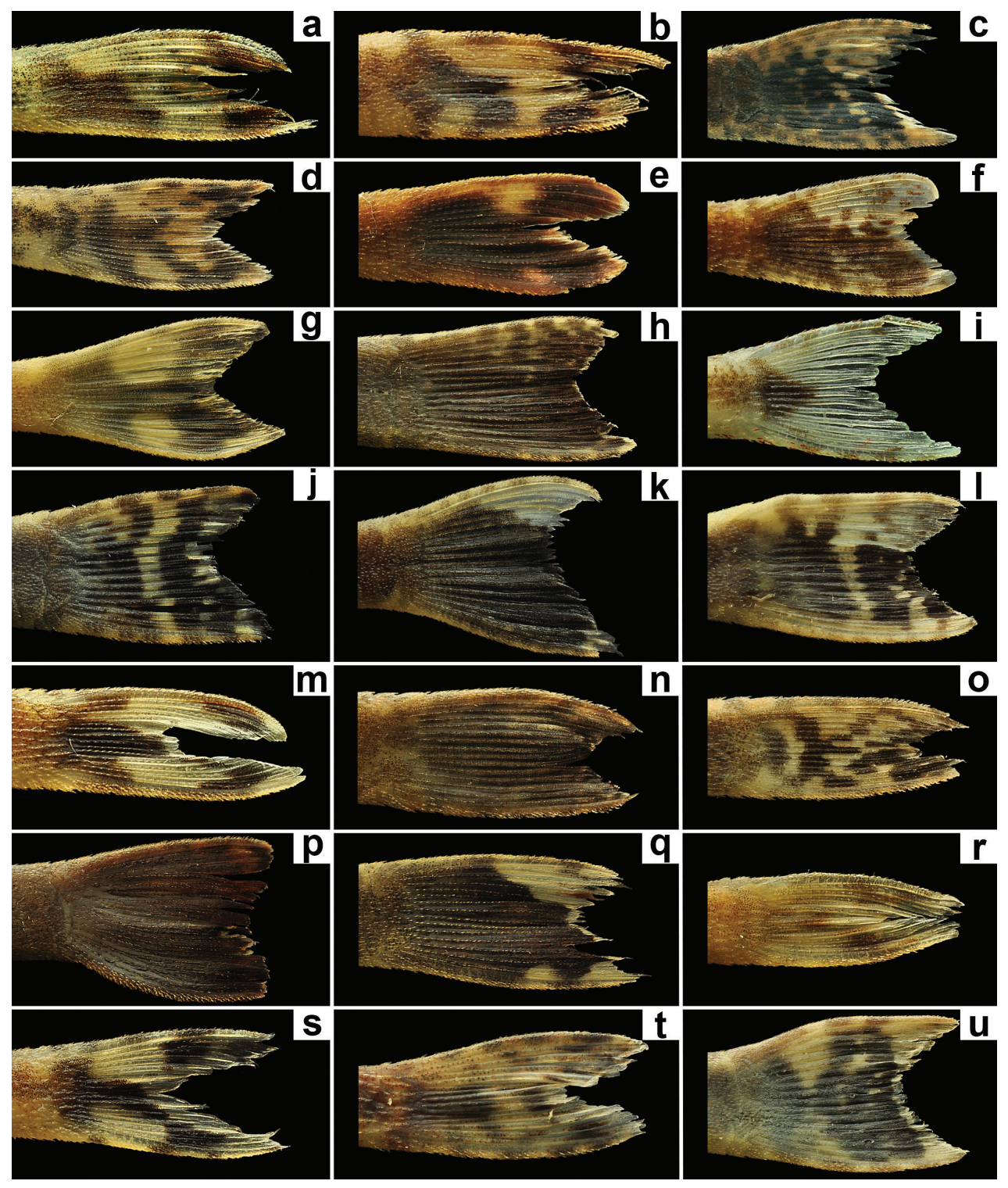

Figure 2. Coloration pattern of caudal fin of Hisonotus species. a H. vespuccii, LBP 19491, $26.2 \mathrm{~mm}$ SL b $H$. acuen, LBP 16279, $26.1 \mathrm{~mm}$ SL c $H$. armatus, LBP 14461, $38.2 \mathrm{~mm}$ SL d H. bocaiuva, LBP 17402, $24.8 \mathrm{~mm}$ SL e $H$. chromodontus, LBP 7964, $27.6 \mathrm{~mm}$ SL f $H$. depressicauda, LBP 1293, $26.1 \mathrm{~mm}$ SL $\mathbf{g} H$. francirochai, LBP 8356, $31.6 \mathrm{~mm}$ SL $\mathbf{h} H$. heterogaster, LBP 14580, $38.7 \mathrm{~mm}$ SL $\mathbf{i} H$. insperatus, LBP 17432, $26.9 \mathrm{~mm}$ SL j H. iota, LBP 13072, $41.5 \mathrm{~mm}$ SL k H. leucofrenatus, LBP 2039, $40.7 \mathrm{~mm}$ SL I H. leucophrys, LBP 13071, $41.1 \mathrm{~mm}$ SL $\mathbf{m}$ H. luteofrenatus, LBP 19534, 30.5 mm SL $\mathbf{n}$ H. megaloplax, LBP 13108, $35.8 \mathrm{~mm}$ SL o H. montanus, LBP 13055, $31.8 \mathrm{~mm}$ SL p H. nigricauda, LBP 14652, 38.5 $\mathrm{mm}$ SL q H. notatus, LBP 18472, $32.0 \mathrm{~mm}$ SL $\mathbf{r}$ H. oliveirai, LBP 13333, $24.0 \mathrm{~mm}$ SL $\mathbf{s} H$. paresi, LBP 13351, $24.6 \mathrm{~mm}$ SL t $H$. piracanjuba, LBP 17256, $22.1 \mathrm{~mm}$ SL u H. vireo, LBP 14452, $35.5 \mathrm{~mm}$ SL. 
Table I. Morphometrics and meristic data for Hisonotus vespuccii, holotype and paratypes measured are from LBP fish collection.

\begin{tabular}{|c|c|c|c|c|c|c|c|c|c|}
\hline \multirow[t]{2}{*}{ Character } & \multirow[t]{2}{*}{ Holotype } & \multicolumn{3}{|c|}{ Males, $\mathbf{n}=21$} & \multicolumn{3}{|c|}{ Females, $n=24$} & \multicolumn{2}{|c|}{$\begin{array}{c}\text { All paratypes, } \\
\mathrm{n}=45\end{array}$} \\
\hline & & Range & Mean & SD & Range & Mean & SD & Mean & SD \\
\hline SL & 32.6 & 24.1-28.7 & 26.2 & 1.4 & $24.4-35.7$ & 30.2 & 2.8 & 28.3 & 3.0 \\
\hline \multicolumn{10}{|l|}{ Percents of SL } \\
\hline Head length & 33.1 & $34.1-37.6$ & 36.1 & 0.8 & $32.7-38.1$ & 35.6 & 1.3 & 35.8 & 1.1 \\
\hline Predorsal length & 44.5 & $44.2-47.3$ & 45.8 & 0.8 & $44.1-48.6$ & 46.1 & 1.2 & 46.0 & 1.0 \\
\hline Dorsal-fin spine length & 22.6 & $22.6-27.2$ & 24.6 & 1.3 & $19.5-25.4$ & 23.2 & 1.1 & 23.8 & 1.4 \\
\hline Anal-fin unbranched ray length & 15.5 & $16.0-19.2$ & 17.4 & 0.8 & $14.9-18.1$ & 16.1 & 0.7 & 16.7 & 1.0 \\
\hline Pectoral-fin spine length & 23.9 & $23.9-29.1$ & 26.0 & 1.3 & $23.1-27.7$ & 25.2 & 1.1 & 25.6 & 1.3 \\
\hline Pelvic-fin unbranched ray length & 16.9 & $17.3-21.5$ & 19.3 & 1.0 & $15.1-18.5$ & 16.8 & 0.8 & 18.0 & 1.5 \\
\hline Cleithral width & 21.5 & $22.3-24.3$ & 23.2 & 0.5 & $21.2-24.9$ & 23.0 & 0.8 & 23.1 & 0.6 \\
\hline Thoracic length & 18.0 & $15.2-18.3$ & 16.5 & 0.7 & $14.9-18.4$ & 16.7 & 0.9 & 16.6 & 0.8 \\
\hline Abdominal length & 22.6 & $20.7-23.1$ & 21.6 & 0.5 & $20.1-24.6$ & 22.5 & 1.1 & 22.1 & 1.0 \\
\hline Body depth at dorsal-fin origin & 14.7 & $14.0-17.7$ & 15.7 & 0.9 & $14.3-17.5$ & 15.9 & 0.8 & 15.8 & 0.9 \\
\hline Caudal-peduncle length & 39.0 & $36.7-40.3$ & 38.6 & 0.8 & $34.0-39.4$ & 37.3 & 1.2 & 37.9 & 1.2 \\
\hline Caudal-peduncle depth & 6.2 & $6.9-8.0$ & 7.4 & 0.3 & $6.2-7.9$ & 7.0 & 0.4 & 7.2 & 0.4 \\
\hline Nares opening & 12.5 & $12.9-18.0$ & 15.3 & 1.3 & $9.6-12.5$ & 11.1 & 0.7 & 13.0 & 2.3 \\
\hline \multicolumn{10}{|l|}{ Percents of HL } \\
\hline Snout length & 48.8 & $45.8-50.6$ & 48.7 & 1.2 & $45.5-50.3$ & 48.9 & 1.1 & 48.8 & 1.2 \\
\hline Orbital diameter & 16.1 & $13.5-16.6$ & 15.5 & 0.7 & $13.4-16.9$ & 14.9 & 0.9 & 15.2 & 0.9 \\
\hline Interorbital width & 36.1 & $35.1-38.7$ & 37.1 & 0.9 & $34.1-39.0$ & 36.2 & 1.3 & 36.6 & 1.2 \\
\hline Head depth & 40.5 & $39.0-45.0$ & 42.0 & 1.5 & $38.6-47.2$ & 42.5 & 1.9 & 42.3 & 1.7 \\
\hline Suborbital depth & 17.2 & $14.9-18.8$ & 16.6 & 0.9 & $14.9-20.3$ & 17.0 & 1.6 & 16.8 & 1.3 \\
\hline Mandibular ramus & 9.7 & $8.1-10.5$ & 9.3 & 0.6 & $8.3-15.6$ & 9.6 & 1.4 & 9.5 & 1.1 \\
\hline \multicolumn{10}{|l|}{ Meristics } \\
\hline Left lateral scutes & 22 & $21-23$ & 22 & - & $21-23$ & 22 & - & 22 & - \\
\hline Left premaxillary teeth & 19 & $15-21$ & 17 & - & $13-21$ & 19 & - & 17 & - \\
\hline Left dentary teeth & 19 & $11-19$ & 14 & - & $13-21$ & 16 & - & 16 & - \\
\hline
\end{tabular}

(medial) cusp large and rounded, minor (lateral) cusp minute and pointed. Accessory patch of teeth absent on dentary and premaxilla. Oral disk oval, covered with papillae uniformly distributed on base of dentary and premaxilla and slightly decreasing in size distally. Lower lip larger than upper lip; its border fringed. Maxillary barbel present and joined to lower lip. Presence of conspicuous $V$-shaped buccal papilla located immediately anterior to buccal valve. Tip of snout with large rostral plate.

Dorsal fin II,7; its origin slightly posterior to pelvic-fin origin. Tip of adpressed dorsal fin surpassing vertically through end of anal-fin origin. Dorsal-fin spinelet short and $V$-shaped; dorsal-fin lock functional. Pectoral fin I,6; its tip reaching middle of pelvic-fin length when depressed. Pectoral-axillary slit present between pectoral-fin insertion and lateral process of cleithrum. Pectoral spine supporting sharp odontodes on dorsal and ventral surfaces (well developed posteriorly). Pelvic fin I,5; its tip reach- 


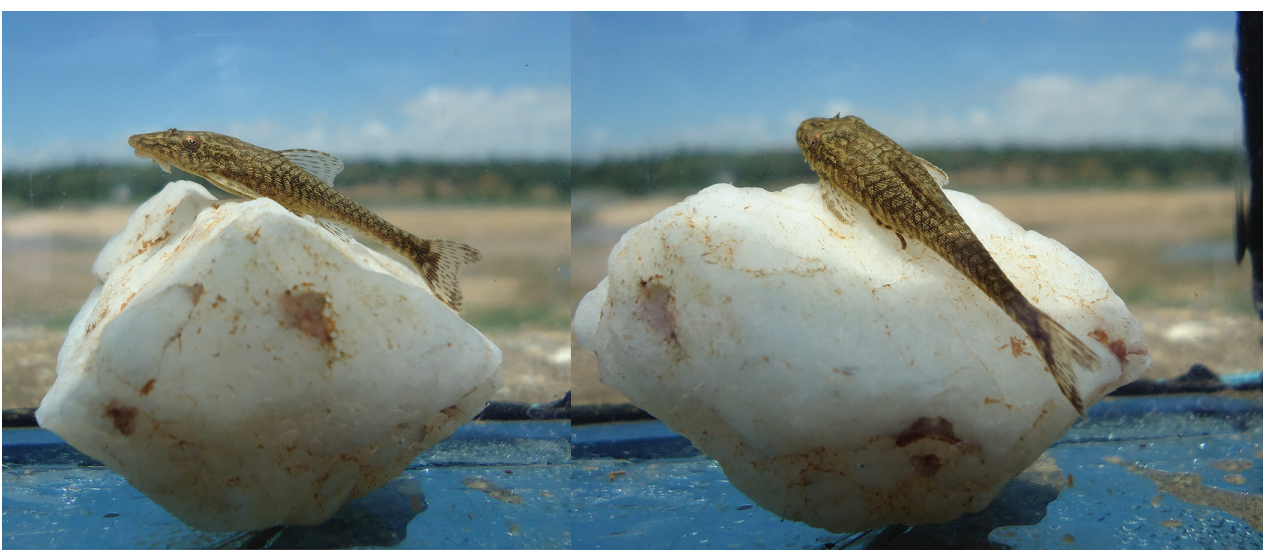

Figure 3. Live specimen of H. vespuccii, LBP 19491, paratype, $32.4 \mathrm{~mm}$ SL, from Minas Gerais State, municipality of Pirapora, rio São Francisco.

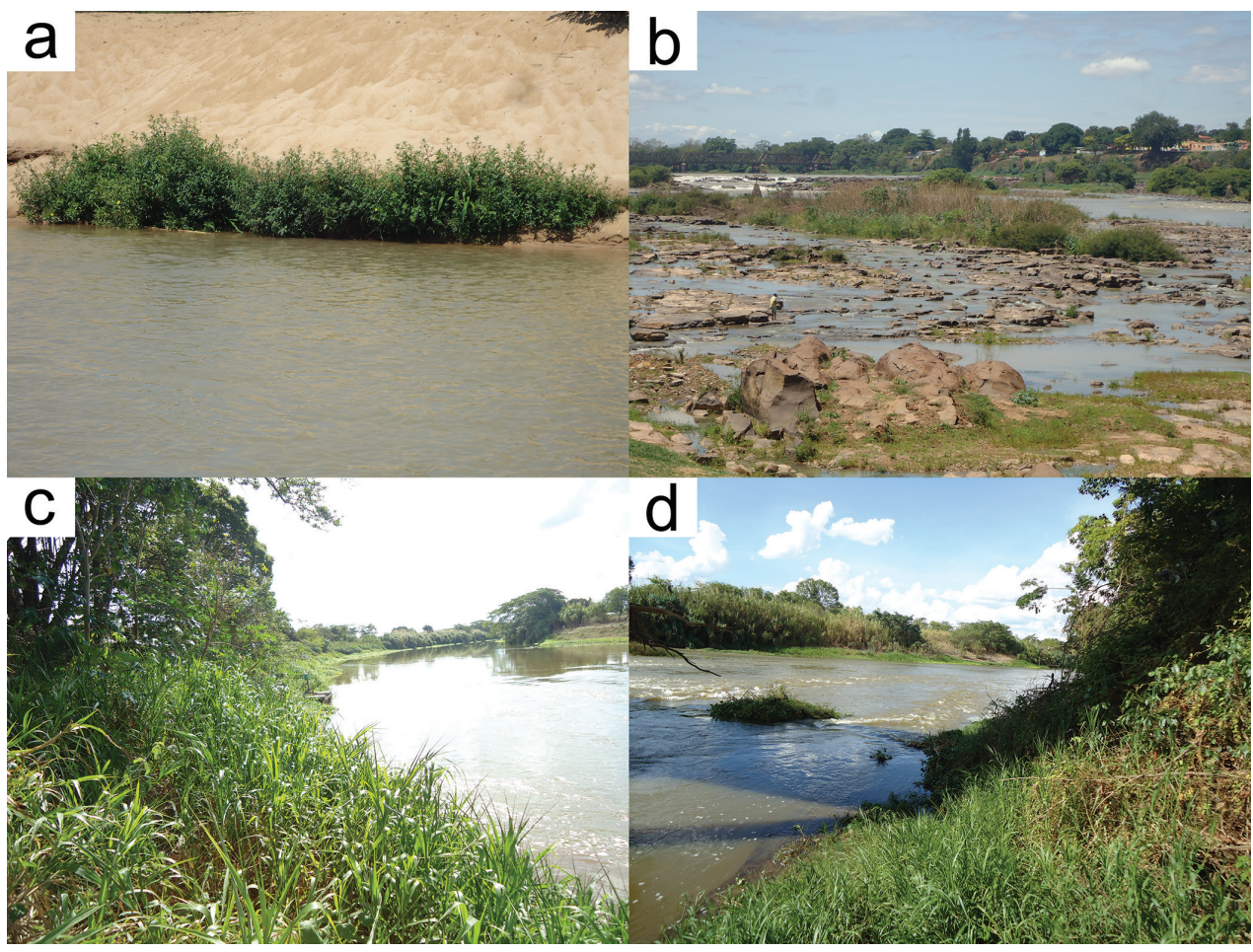

Figure 4. (a) (b) Type locality of $H$. vespuccii at rio São Francisco, municipality of Pirapora, Minas Gerais State, $17^{\circ} 21^{\prime} 00^{\prime \prime S}, 44^{\circ} 57^{\prime} 08^{\prime \prime W}$. (c) (d) Paratypes locality of H. vespuccii at rio das Velhas, municipality

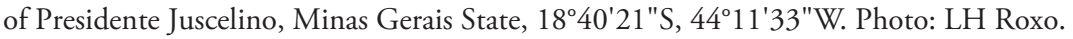

ing anal-fin origin when depressed in males and far from reaching anal-fin origin in females. Pelvic-fin unbranched ray with dermal flap along its dorsal surface in males. Pectoral spine supporting sharp odontodes on ventral surface turned mesially. 


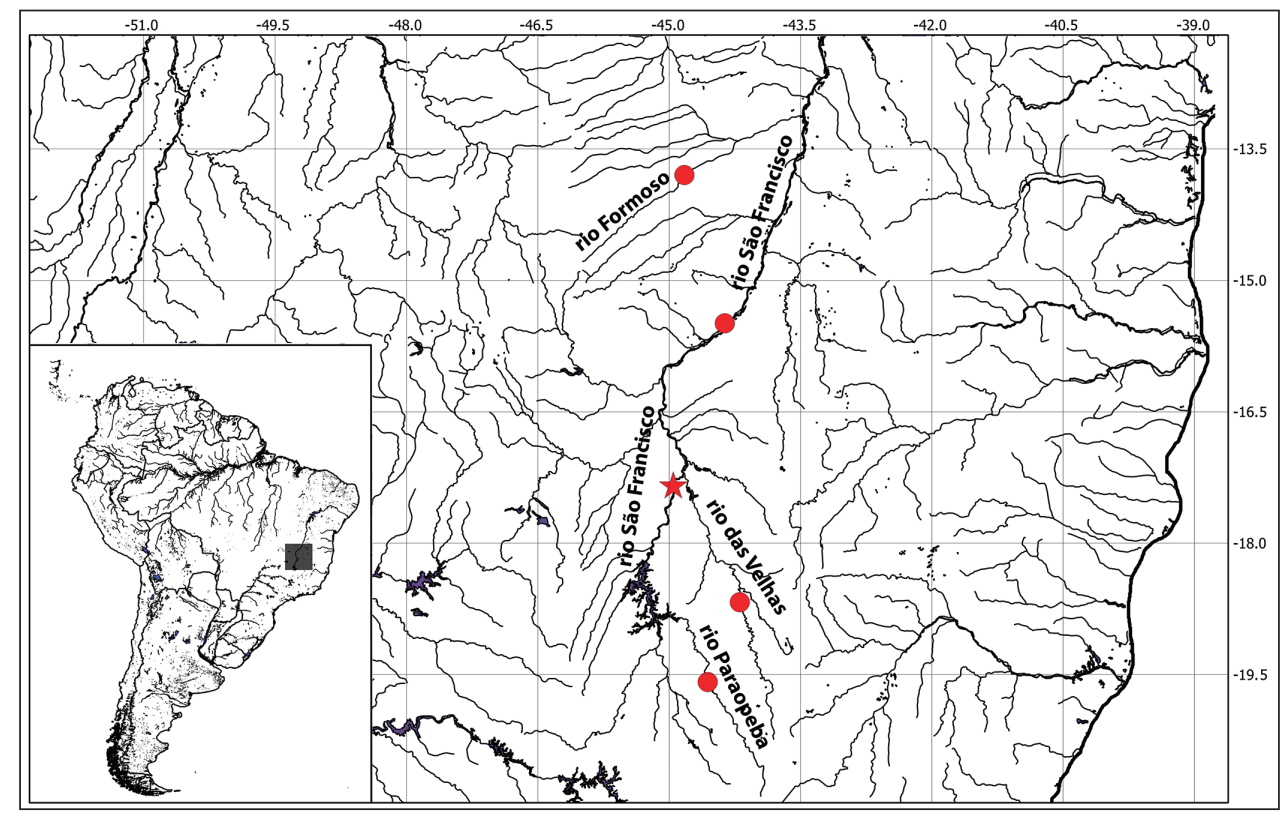

Figure 5. Map of the distribution of $H$. vespuccii. Red Star = type locality, at rio São Francisco, municipality of Pirapora, Minas Gerais State. Red Circles = paratypes localities of H. vespuccii at rio das Velhas, rio Paraopeba and rio Formoso, Minas Gerais State.

Anal fin i,5; its tip reaching seventh or eighth plate from its origin. Caudal-fin i,77,I; distal margin forked. Adipose fin absent. Total vertebrae 27 (in 7 c\&s specimens). Body almost entirely covered by bone plates, except on ventral portion of head, around pectoral- and pelvic-fin origins, on dorsal-fin base and area around anus. Abdomen partially covered by bony plates randomly distributed and surrounded by naked areas (in some specimens abdomen is completely covered by bony plates). Laterally, body completely covered by plates; mid-dorsal and mid-ventral plate series well developed reaching vertical through half of caudal peduncle; median plate series continuous in median portion of body. Coracoid and cleithrum completely exposed, covered with odontodes. Arrector fossae partially enclosed by ventral lamina of coracoids.

Color in alcohol. Ground color of dorsal surface of head and body dark gray to lighter brown (juveniles lighter than adults). Ventral surface light brown to yellow in juveniles. All body and fins covered by scattered chromatophores, more visible on ventral portions and around fins insertions (Fig. 1). Caudal-fin hyaline, except for one black spot at its origin extending to ventral lobe and two dark spots at end of rays (Fig. 2a). In some specimens, caudal-fin with chromatophores irregular distributed and sometimes badly forming two dark strips (more visible in juveniles). Neither variation nor variability of caudal-fin coloration patter found in samples we examined (holotype and 249 specimens widely distributed in rio São Francisco basin) with specific emphasis to variability between populations and variation depending on feeding. 
Color in life. Similar to pattern described for alcohol individuals, but with ground color light green (Fig. 3).

Sexual dimorphism. Adult males distinguished from females by five characters: (1) presence of a papilla at urogenital opening in males ( $v s$. papilla absent in females); (2) pelvic-fin extending beyond anal-fin origin in males, mean 19\% SL (vs. pelvic fin far from reaching anal-fin origin in females, mean 17\% SL); (3) unbranched pelvic-fin ray supporting a dermal flap (flap slightly wider in basal portion and progressively narrowing distally) on proximal dorsal surface in males (vs. dermal flap absent in females); (4) nares opening wider in males (13-18\% HL) than females (10-13\% HL); (5) body size smaller in males (mean $26 \mathrm{~mm} \mathrm{SL}$ ) and larger in females (mean $30 \mathrm{~mm} \mathrm{SL}$ ). See Table 1 for values of morphometric characters between males and females.

Habitat and distribution. Hisonotus vespuccii was found associated with marginal vegetation (Fig. 4) in the rio São Francisco and in three of its tributaries, rio das Velhas, rio Paraopeba and rio Formoso (Fig. 5). The new species seems to be abundant through all rio São Francisco basin.

Etymology. The specific name "vespuccii" comes from Italian and is in reference to Américo Vespúcio (Amerigo Vespucci in Italian), navigator and explorer to whom is attributed the discovery of the rio São Francisco in 1501.

\section{Comparative remarks and discussion}

The new species $H$. vespuccii has one character proposed by Schaefer (1998) to diagnose the genus Hisonotus: the rostrum with enlarged odontodes. Moreover, the new species also shares three characters with many species of Hisonotus: a single rostral plate on the tip of the snout, an arrector fossae partially enclosed by a ventral lamina of the coracoid, a character also used by Schaefer (1998) as synapomorphy of all Otothyrini except the New Taxon 3, and a functional $V$-shaped spinelet. This last character was firstly proposed by Carvalho and Datovo (2012) with pers. comm. of Roberto E. Reis, and posteriorly was reported by Silva et al. (2014) as a possible synapomorphy that may help delimit a new genus within Hisonotus. However, to better understand the relationship of the new species with other species assigned to Hisonotus a phylogenetic analysis is still necessary.

We used seven characters to distinguish the new species $H$. vespuccii from congeners. The first character was the caudal fin with one black spot extending from its origin to the ventral lobe and two dark spots at the end of the lobe's rays, a pattern unique among Hisonotus species (see Fig. 2b-u for caudal-fin coloration pattern of some species of Hisonotus). Britski and Garavello (2007) discussing about the coloration pattern of the teeth in H. chromodontus Britski \& Garavello, 2007 suggested that this aspect of the organism could be a result of physiological features changing according to the individual's foraging success and physiological efficiency, as well as according to the characteristics of the water where the species lives. However, the pattern of caudal-fin coloration seems to be conserved among species of Hisonotus (Fig. 2), with a pattern 
varying more drastically in $H$. acuen Silva, Roxo \& Oliveira, 2014, a species widely distributed through headwaters of the rio Xingu basin (see Fig. 5 in Silva et al. 2014). In $H$. vespuccii, the pattern of the caudal-fin with one black spot extending from its origin to the ventral lobe and two dark spots at the end of the lobe's rays is present in the holotype and the 249 paratypes analyzed.

Moreover, the new species $H$. vespuccii was distinguished from congeners by present a combination of the following characters: (2) odontodes forming longitudinally aligned rows (one odontode after the other, but not necessarily forming parallel series) on head and trunk, a character shared with $H$. insperatus, $H$. luteofrenatus, $H$. oliveirai, and $H$. paresi; (3) a functional $V$-shaped spinelet as reported previously (see Fig. 2 in Silva et al. 2014 to description of this character state) shared with $H$. acuen, $H$. bockmanni, $H$. chromodontus, $H$. insperatus, $H$. luteofrenatus, $H$. oliveirai, $H$. paresi, and $H$. piracanjuba; (4) the presence of a single rostral plate at tip of the snout, a character also present in $H$. insperatus, $H$. luteofrenatus, $H$. oliveirai, $H$. paresi, and $H$. piracanjuba; (5) the lacking of contrasting dark geometric spots on the anterodorsal region of the body, a character used to distinguish the new species of $H$. bockmanni and $H$. paresi; (6) a lower caudal-peduncle depth (6.2-8.0\% of SL) used to distinguish the new species of $H$. acuen (8.6-11.1\% of SL); and (7) lower counts of the lateral median plates (21-23) and higher counts of premaxillary (13-21) and dentary teeth (11-21) used to distinguish $H$. vespuccii of $H$. insperatus (25-26; 10-12; 8-11, respectively).

Members of Loricariidae are known to have intense sexual dimorphisms (Py-Daniel and Fernandes 2005) as we can observe in species of the genera Ancistrus Kner, 1854 (Sabaj et al. 1999), Neoplecostomus Eigenmann \& Eigenmann, 1888 (Zawadzki et al. 2008; Roxo et al. 2012; Andrade and Langeani 2014), Pareiorhaphis Miranda Ribeiro, 1918a (Pereira et al. 2007), Hisonotus (Martins and Langeani 2012), Hypostomus Lacepède, 1803 and Chaetostoma Tschudi, 1846 (Nomura and Mueller 1980; Lopez and Roman-Valencia 1996), Farlowella Eigenmann \& Eigenmann, 1889 (Retzer and Page 1996) and many other. In $H$. vespuccii, we observed five sexual dimorphic characters: the presence of a papilla at the urogenital opening, a pelvic-fin that extends beyond the anal-fin origin, the unbranched pelvic-fin ray supporting a dermal flap on their proximal dorsal surface, the nares opening wider and a body size that seems to be smaller in males than in females. The first three characters are very common among species of Hisonotus, however differences in size of nares were only previously reported in the original description of $H$. piracanjuba (Martins and Langeani 2012) and differences in body size in H. ringueleti (Aquino et al. 2001). Carvalho and Reis (2009) reported that the presence of the dermal flap on proximal dorsal surface of pelvic-fin on males is a plesiomorphic character shared among most members of Otothyrinae and that the derived condition evolved several times within this subfamily at the genera Schizolecis Britski \& Garavello, 1984, Epactionotus Reis \& Schaefer, 1998, and within Hypoptopomatinae in Acestridium Haseman, 1911, Oxyropsis Eigenmann \& Eigenmann, 1889 and Hypoptopoma Günther, 1868. 


\section{Comparative material}

All from Brazil, except when stated otherwise.

Hisonotus acuen Silva, Roxo \& Oliveira, 2014: MZUSP 115350, 1, 25.9 mm SL, holotype, tributary of rio Toguro, Querência, Mato Grosso State; LBP 15755, 16, 19.5-26.0 mm SL, paratypes, tributary of rio Suiá-Missu, ribeirão Cascalheira, Mato Grosso State; LBP 16274, 27, 20.2-29.1 mm SL, 2 c\&s, 23.6-24.2 mm SL, paratypes, tributary of rio Culuene, Gaúcha do Norte, Mato Grosso State; LBP 16275, 29, 16.7-25.2 mm SL, 2 c\&s, 19.3-20.8 mm SL, paratypes, tributary of rio Feio, Querência, Mato Grosso State; LBP 16278, 12, 18.8-25.1 mm SL, 2 c\&s, 26.8-27.1 mm SL, paratypes, córrego Xavante, Primavera do Leste, Mato Grosso State.

Hisonotus aky (Azpelicueta, Casciotta, Almirón \& Koerber, 2004): MHNG 2643.039, 2, 33.1-34.2 mm SL, paratypes, arroio Fortaleza, Argentina.

Hisonotus armatus Carvalho, Lehmann, Pereira \& Reis, 2008: MZUSP 93884, 5, 37.644.4 mm SL, paratypes, arroio Arambaré, Pedro Osório, Rio Grande do Sul State.

Hisonotus bocainva Roxo, Silva, Oliveira \& Zawadzki, 2013: MZUSP 112204, 1, 24.2 mm SL, holotype, córrego Cachoeira, Bocaiúva, Minas Gerais State; LBP 9817, 9, 3 c\&s, 18.3-23.2 mm SL, paratypes, córrego Cachoeira, Bocaiúva, Minas Gerais State.

Hisonotus brunneus Carvalho \& Reis, 2011: MZUSP 104947, 4, 37.2-41.3 mm SL, paratypes, rio Passo Novo, Cruz Alta, Rio Grande do Sul State.

Hisonotus carreiro Carvalho \& Reis, 2011: MCP 40943, 3, 33.6-35.8 mm SL, arroio Guabiju, Guabiju, Rio Grande do Sul State.

Hisonotus charrua Almirón, Azpelicueta, Casciotta \& Litz, 2006: LBP 4861, 1, 35.9 mm SL, arroio Guaviyú, Artigas, Uruguay; MHNG 2650.051, 1, 34.2 mm SL, paratype, arroio Aspinillar, Uruguay.

Hisonotus chromodontus Britski \& Garavello, 2007: LBP 7964, 25, 24.0-28.3 mm SL, 4 c\&s, 24.9-28.9 mm SL, rio dos Patos, Nova Mutum, Mato Grosso State; LBP 7974, 26, 17.7-24.8 mm SL, rio dos Patos, Nova Mutum, Mato Grosso State; LBP 12278, 2, 26.7-28.7 mm SL, 1 c\&s, 26.7 mm SL, rio Sumidouro, Tangará da Serra, Mato Grosso State; MZUSP 45355, 1, 25.9 mm SL, holotype, tributary of rio Preto, Diamantino, Mato Grosso State; MZUSP 70758, 7, 19.4-23.9 mm SL, paratype, riacho Loanda, Sinop, Mato Grosso State; NUP 10924, 24, 19.5-31.5 mm SL, rio Preto, Diamantino, Minas Gerais State.

Hisonotus depressicauda (Miranda Ribeiro, 1918b): MZUSP 5383, 1, $24.4 \mathrm{~mm} \mathrm{SL}$, paralectotype, Sorocaba, São Paulo State; LBP 17474, 5 c\&s, 18.1-24.0 mm SL, rio Araquá, Botucatu, São Paulo State.

Hisonotus francirochai (Ihering, 1928): LBP 13923, 22, 25.7-35.7 mm SL, córrego sem nome, Capetinga, Minas Gerais State; MZUSP 3258, 1, 29.4 mm SL, lectotype, rio Grande, São Paulo State.

Hisonotus heterogaster Carvalho \& Reis, 2011: LBP 3335, 39, 20.8-30.1 mm SL, arroio sem nome, rio Grande, Rio Grande do Sul State; MZUSP 104948, 3, 40.3-43.0 mm SL, paratypes, arroio Felício, Júlio de Castilho, Rio Grande do Sul State. 
Hisonotus insperatus Britski \& Garavello, 2003: LBP 4945, 5, 27.3-28.5 mm SL, 2 c\&s, 28.2-29.9 mm SL, Botucatu, São Paulo State; LBP 6770, 5, 25.1-28.2 mm SL, 3 c\&s, 20.0-27.0 mm SL, ribeirão Cubatão, Marapoama, São Paulo State; LBP 13336, 1 c\&s, 26.0 mm SL, rio Capivara, Botucatu, São Paulo State; LBP 13337, 2 c\&s, 27.4-28.6 mm SL, rio Araquá, Botucatu, São Paulo State; MZUSP 22826, 1, 25.4 mm SL, paratype, córrego Água Tirada, Três Lagoas, Minas Gerais State; MZUSP 24832, 1, 23.8 mm SL, paratype, rio Corumbataí, Corumbataí, Sáo Paulo State; MZUSP 78957, 1, 29.6 mm SL, holotype, rio Capivara, Botucatu, São Paulo State; MZUSP 78960, 31, 12.6-26.0 mm SL, paratypes, 5 c\&s, 22.7-24.7 mm SL, rio Pardo, Botucatu, São Paulo State; MZUSP 78965, 10, 15.6-28.6 mm SL, paratypes, rio Araquá, Botucatu, São Paulo State; MZUSP 78968, 5, 24.1-27.3 mm SL, paratypes, córrego da Figueira, Lins, São Paulo State. Hisonotus iota Carvalho \& Reis, 2009: LBP 13072, 5, 32.3-33.0 mm SL, rio Chapecó, Coronel Freitas, Santa Catarina State.

Hisonotus laevior Cope, 1894: LBP 3377, 1, 25.2 mm SL, arroio dos Corrientes, Pelotas, Rio Grande do Sul State; LBP 6037, 8, 33.4-47.0 mm SL, rio Maquiné, Osório, Rio Grande do Sul State; LBP 13187, 7, 19.4-45.8 mm SL, córrego sem nome, Camaquá, Rio Grande do Sul State.

Hisonotus leucofrenatus (Miranda Ribeiro, 1908): LBP 2085, 7, 38.3-50.6 mm SL, rio Sagrado, Morretes, Paraná State; LBP 6837, 36, 35.1-43.5 mm SL, rio Fau, Miracatu, São Paulo State.

Hisonotus leucophrys Carvalho \& Reis, 2009: LBP 13065, 6, 17.2-33.6 mm SL, rio Ariranhas, Xavantina, Santa Catarina State; LBP 13073, 1, 36.8 mm SL, rio Guarita, Palmitinho, Rio Grande do Sul State.

Hisonotus luteofrenatus Britski \& Garavello, 2007: MZUSP 62593, 1, 28.6 mm SL, holotype, córrego Loanda, Cláudia, Mato Grosso State; MZUSP 62594, 8, 22.4-30.5 mm SL, paratypes, riacho Selma, Sinop, Mato Grosso State; MZUSP 87144, 8, 16.8-27.9 mm SL, paratypes, córrego Loanda, Cláudia, Mato Grosso State.

Hisonotus megaloplax Carvalho \& Reis, 2009: LBP 13108, 6, 36.4-37.8 mm SL, córrego sem nome, Saldanha Marinho, Rio Grande do Sul State.

Hisonotus montanus Carvalho \& Reis, 2009: LBP 13051, 3, 26.4-27.2 mm SL, rio Goiabeiras, Vargem, Santa Catarina State; LBP 13055, 5, 24.8-31.9 mm SL, rio Canoas, Vargem, Santa Catarina State.

Hisonotus nigricauda (Boulenger, 1891): LBP579, 16, 34.1-40.1 mm SL, rio Guaíba, Eldorado do Sul, Rio Grande do Sul State.

Hisonotus notatus Eigenmann \& Eigenmann, 1889: LBP 3472, 20, 21.0-34.3 mm SL, 3 c\&s, 25.8-26.5 mm SL, rio Aduelas, Macaé, Rio de Janeiro State; LBP 10742, 25, 24.4-43.3 mm SL, rio Macabu, Conceição de Macabu, Rio de Janeiro State.

Hisonotus notopagos Carvalho \& Reis, 2011: MZUSP 104943, 4, 35.3-37.3 mm SL, arroio Boici, Pinheiro Machado, Rio Grande do Sul State.

Hisonotus oliveirai Roxo, Zawadzki \& Troy, 2014b: MZUSP 115061, 1, $26.4 \mathrm{~mm}$ SL, holotype, ribeirão Cambira, tributary of rio Ivaí, Cambira, Paraná State; LBP 13332, 123.2 mm SL, 1 c\&s, 23.7 mm SL, paratype, rio Mourão, Campo 
Mourão, Paraná State; LBP 17578, 5, 25.4-30.4 mm SL, paratypes, rio Mourão, between Engenheiro Beltrão and Quinta do Sol, Paraná State; NUP 3578, 15, 24.7-28.1 mm SL, 2 c\&s, 25.5-27.6 mm SL, paratypes, ribeirão Salto Grande, Maria Helena, Paraná State.

Hisonotus paresi Roxo, Zawadzki \& Troy, 2014b: MZUSP 115062, 1, 26.2 mm SL, holotype, riacho Águas Claras, Santo Afonso, Mato Grosso State; LBP 13351, 9 , 14.7-24.3 mm SL, paratype, riacho Águas Claras, Santo Afonso, Mato Grosso State; LBP 13352, 1, $23.7 \mathrm{~mm} \mathrm{SL}$, paratype, riacho Águas Claras, Santo Afonso, Mato Grosso State; NUP 10928, 2, 23.2-24.2 mm SL, paratype, 2 c\&s, 23.6-24.2 mm SL, riacho Águas Claras, Santo Afonso, Mato Grosso State; NUP 10976, 3, 16.7-20.5 mm SL, paratype, riacho São Jorge, Santo Afonso, Mato Grosso State.

Hisonotus piracanjuba Martins \& Langeani, 2012: LBP 17256, 9, 17.2-26.3 mm SL, 1 c\&s, 27.1 mm SL, córrego sem nome, Morrinhos, Goiás State; NUP 5059, 1, 24.7 mm SL, córrego Posse, Anápolis, Goiás State; MZUSP 110491, 3, 17.5-24.4 mm SL, paratypes, rio Quente, Marcelánia, Goiás State; NUP 10979, 3, 21.4-21.8 $\mathrm{mm}$ SL, ribeirão Bocaina, Piracanjuba, Goiás State.

Hisonotus prata Carvalho \& Reis, 2011: MCP 40492, 18, 19.5-33.2 mm SL, rio da Prata, Nova Prata, Rio Grande do Sul State; LBP 9918, 14, 21.7-32.6 mm SL, Laguna dos Patos system, Nova Prata, Rio Grande do Sul State.

Hisonotus ringueleti Aquino, Schaefer \& Miquelarena, 2001: FMNH 108806, 2, 25.7-32.2 mm SL, rio Quaraí basin, Uruguay; LBP 13148, 1, $24.5 \mathrm{~mm} \mathrm{SL,} \mathrm{arroio}$ Putiá, Uruguaiana, Rio Grande do Sul State.

Hisonotus vireo Carvalho \& Reis, 2011: MZUSP 104946, 4, 30.4-39.5 mm SL, rio dos Sinos, Caraá, Rio Grande do Sul State.

Hisonotus sp. 1 n.: LBP 8276, 1 c\&s, 25.6 mm SL, rio Verde Grande, Jaíba, Minas Gerais State.

Hisonotus sp. 2 n.: MZUSP 95687, 8, 19.8-21.5 mm SL, ribeirão da Anta, Gaúcha do Norte, Mata Grosso State.

Hisonotus sp. 3 n.: MZUSP 84157, 6, 20.1-23.6 mm SL, rio Manuel Alves, Porto Alegre do Tocantins, Tocantins State.

Microlepidogaster arachas Martins, Calegari \& Langeani, 2013: LBP 10882, 3, 22.8-35.3 mm SL, rio Paraná basin, Arachas, Minas Gerais State.

Microlepidogaster dimorpha Martins \& Langeani, 2011: LBP 10683, 2, 28.8-35.6 mm SL, rio Uberaba, Uberaba, Minas Gerais State.

Otothyropsis marapoama Ribeiro, Carvalho \& Melo, 2005: LBP 4698, 6, 23.9-36.3 mm SL, ribeirão Cubatão, Marapoama, São Paulo State.

Parotocinclus maculicauda (Steindachner, 1877): LBP 2869, 15, 20.2-44.7 mm SL, rio Fau, Miracatu, São Paulo State.

Parotocinclus prata Ribeiro, Melo \& Pereira, 2002: LIRP 1136, 38, 19.8-41.9 mm SL, paratypes, ribeirão Quiricó, Presidente Olegário, Minas Gerais State.

Parotocinclus robustus Lehmann \& Reis, 2012: LBP 8258, 29, 18.7-39.1 mm SL, córrego Cachoeira, Bocaiúva, Minas Gerais State. 


\section{Acknowledgements}

The authors wish to thank Bruno F Melo, Carlos BM Alves, Guilherme JC Silva, José A Senhorini, Júlio C Garavello, Luiz H Roxo, Luz E Ochoa, Mahmoud Mehanna, Roberto E Reis and Yoshimi Sato for their help during the collection expeditions; Margarete Penteado for English revision. Research was supported by Brazilian agencies FAPESP (Fundação de Amparo à Pesquisa do Estado de São Paulo, proc. 2014/05051-5 to FFR, and proc. 2012/01622-2 to GSCS), MCT/CNPq (Conselho Nacional de Desenvolvimento Científico e Tecnológico) (Edital Universal, proc. N. 441347/2014-2 coord. FFR).

\section{References}

Almirón AE, Azpelicueta MM, Casciotta JR, Litz T (2006) A new species of Hisonotus (Siluriformes, Loricariidae, Otothyrini) from the República Oriental del Uruguay. Revue suisse de Zoologie 113(1): 87-94.

Andrade BN, Langeani F (2014) A new species of Neoplecostomus Eigenmann \& Eigenmann, 1888 (Siluriformes: Loricariidae: Neoplecostominae) from the upper rio Paraná basin, 1-7. doi: 10.1590/1982-0224-20130195

Aquino AE, Schaefer SA, Miquelarena AM (2001) A new species of Hisonotus (Siluriformes, Loricariidae) of the Upper Río Uruguay basin. American Museum Novitates 3333: 1-12. doi: 10.1206/0003-0082(2001)333<0001:ANSOHS>2.0.CO;2

Armbruster JW (2004) Phylogenetic relationships of the sucker-mouth armored catfishes (Loricariidae) with particular emphasis on the Hypostominae and the Ancistrinae. Zoological Journal of the Linnean Society 141: 1-80. doi: 10.1111/j.1096-3642.2004.00109.x

Azpelicueta MM, Casciotta JR, Almirón AE, Koerber S (2004) A new species of Otothyrini (Siluriformes: Loricariidae: Hypoptopomatinae) from the Río Uruguay basin, Argentina. Verhandlungen der Gesellschaft für Ichthyologie 4: 81-90.

Boulenger GA (1891) An account of the siluroid fishes obtained by Dr. H. von Ihering and Herr Sebastian Wolff in the Province Rio Grande do Sul, Brazil. Proceedings of the Zoological Society of London 2: 231-235.

Britski HA, Garavello JC (1984) Two new southeastern Brazilian genera of Hypoptopomatinae and a redescription of Pseudotocinclus Nichols, 1919 (Ostariophysi, Loricariidae). Papéis Avulsos do Departamento de Zoologia (São Paulo) 35(21): 225-241.

Britski HA, Garavello JC (2003) Hisonotus insperatus: new species, from the upper rio Paraná basin (Pisces: Ostariophysi: Loricariidae). Copeia 2003(3): 588-593. doi: 10.1643/CI-02-23R

Britski HA, Garavello JC (2007) Description of two new sympatric species of the genus Hisonotus Eigenmann and Eigenmann, 1889, from upper rio Tapajós, Mato Grosso state, Brazil (Pisces: Ostariophysi: Loricariidae). Brazilian Journal of Biology 67(3): 413-420. doi: 10.1590/S1519-69842007000300005

Carvalho TP, Lehmann PA, Pereira EHL, Reis RE (2008) A New Species of Hisonotus (Siluriformes: Loricariidae: Hypoptopomatinae) from the Laguna dos Patos basin, Southern Brazil. Copeia 3(3): 510-516. doi: 10.1643/CI-07-130 
Carvalho TP, Reis RE (2009) Four new species of Hisonotus (Siluriformes: Loricariidae) from the upper rio Uruguay, southeastern South America, with a review of the genus in the rio Uruguay basin. Zootaxa 2113: 1-40.

Carvalho TP, Reis RE (2011) Taxonomic review of Hisonotus Eigenmann and Eigenmann (Siluriformes: Loricariidae: Hypoptopomatinae) from the laguna dos Patos system, southern Brazil. Neotropical Ichthyology 9(1): 1-48. doi: 10.1590/S0074-02762011000900001

Chiachio MC, Oliveira C, Montoya-Burgos JI (2008) Molecular systematic and historical biogeography of the armored Neotropical catfishes Hypoptopomatinae and Neoplecostominae (Siluriformes: Loricariidae). Molecular Phylogenetic and Evolution 49: 606-617. doi: 10.1016/j.ympev.2008.08.013

Cope ED (1894) On the fishes obtained by the Naturalist Expedition in Rio Grande do Sul. Proceedings of the American Philosophical Society 33: 84-108, Pls. 4-9.

Eigenmann CH, Eigenmann RS (1888) Preliminary notes on South American Nematognathi. I. Proceedings of the California Academy of Sciences 1(2): 119-172.

Eigenmann CH, Eigenmann RS (1889) Preliminary notes on South American Nematognathi. Proceedings of the California Academy of Sciences 1: 119-172.

Günther A (1868) Diagnoses of some new freshwater fishes from Surinam and Brazil, in the collection of the British Museum. Annals and Magazine of Natural History 1(6): 475-481. doi: $10.1080 / 00222936808695733$

Haseman JD (1911) Descriptions of some new species of fishes and miscellaneous notes on others obtained during the expedition of the Carnegie Museum to central South America. Annals of the Carnegie Museum 7 (3-4) (17): 315-328, Pls. 46-52.

Ihering R von (1928) Uma nova espécie de Otocinclus (Pisces. Nematognatha) "cascudinho" de S. Paulo. Boletim Biologia, Trabalho Laboratório de Parasitologia Faculdade de Medicina, São Paulo 11(42): 1-3.

International Commission on Zoological Nomenclature (1999) International code of zoological nomenclature. Fourth Edition. The International Trust for Zoological Nomenclature, London.

Kner R (1854) Die Hypostomiden. Zweite Hauptgruppe der Familie der Panzerfische. (Loricata vel Goniodontes). Denkschriften der Kaiserlichen Akademie der Wissenschaften in Wien, Mathematisch-Naturwissenschaftliche Classe 7: 251-286.

Lacépède BGE (1803) Histoire naturelle des poissons. Vol. 5. P. Plassan, Paris (ed.) 5(1): i-lxviii, $1-803$.

Lehmann AP, Reis RE (2012) A new species of Parotocinclus (Siluriformes: Loricariidae) from the upper Rio São Francisco, Brazil. Zootaxa 3390: 56-64.

Lopez J, Roman-Valencia C (1996) Sobre la biologia del corroncho Chaetostoma fischeri (Steindachner, 1879) (Pisces: Loricariidae) en el río de La Vieja, Alto Cauca, Colombia. Boletin Ecotrópica Ecossistemas Tropicales 3: 37-57.

Martins FO, Calegari BB, Langeani F (2013) Microlepidogaster arachas, a new species of hypoptopomatine catfish (Siluriformes: Loricariidae) from the upper rio Paraná basin, Brazil. Zootaxa 3608(5): 379-388. doi: 10.11646/zootaxa.3608.5.6

Martins FO, Langeani F (2011) Microlepidogaster dimorpha, a new species of Hypoptopomatinae (Siluriformes: Loricariidae) from the upper Rio Paraná system. Neotropical Ichthyology 9(1): 79-86. doi: 10.1590/S1679-62252011000100005 
Martins FO, Langeani F (2012) Hisonotus piracanjuba, a new species of Hypoptopomatinae (Siluriformes: Loricariidae) from the rio Paranaíba, upper rio Paraná system, central Brazil. Ichthyological Exploration of Freshwaters 23: 29-36.

Miranda Ribeiro A de (1908) Peixes da Ribeira. Resultados de excursão do Sr. Ricardo Krone, membro correspondente do Museu Nacional do Rio de Janeiro. Kosmos, Rio de Janeiro 5(2): 5.

Miranda Ribeiro A de (1918a) Hemipsilichthys, Eignm. \& Eignm., e gêneros aliados. Revista da Sociedade Brasileira de Ciências (Rio de Janeiro) 2: 101-107.

Miranda Ribeiro A de (1918b) Três gêneros e dezessete espécies novas de peixes Brasileiros. Revista do Museu Paulista 10: 631-646.

Nomura H, Mueller IMM (1980) Biologia do cascudo, Plecostomus hermanni Ihering, 1905 do Rio Mogi Guaçu, São Paulo (Osterichthyes, Loricariidae). Revista Brasileira de Biologia 40(2): 267-275.

Pereira EHL, Vieira F, Reis RE (2007) A new species of sexually dimorphic Pareiorhaphis Miranda Ribeiro, 1918 (Siluriformes: Loricariidae) from the rio Doce basin, Brazil. Neotropical Ichthyology 5(4): 443-448. doi: 10.1590/S1679-62252007000400003

Py-Daniel LHR, Fernandes CC (2005) Dimorfismo sexual em Siluriformes e Gymnotiformes (Ostariophysi) da Amazônia. Acta Amazonica 35(1): 97-110. doi: 10.1590/S004459672005000100015

Reis RE, Pereira EHL, Armbruster JW (2006) Delturinae, a new loricariid catfish subfamily (Teleostei, Siluriformes), with revisions of Delturus and Hemipsilichthys. Zoological Journal of the Linnean Society 147: 277-299. doi: 10.1111/j.1096-3642.2006.00229.x

Reis RE, Schaefer SA (1998) New cascudinhos from southern Brazil: systematics, endemism, and relationships (Siluriformes, Loricariidae, Hypoptopomatinae). American Museum Novitates 3254: 1-25.

Retzer ME, Page LM (1996) Systematics of the stick catfishes, Farlowella Eigenmann \& Eigenmann (Pisces, Loricariidae). Proceedings of the Academy of Natural Sciences of Philadelphia 147: 33-88.

Ribeiro AC, Carvalho M, Melo ALA (2005) Description and relationships of Otothyropsis marapoama, a new genus and species of Hypoptopomatinae catfish (Siluriformes: Loricariidae) from rio Tietê basin, southeastern Brazil. Neotropical Ichthyology 3(4): 489-498. doi: 10.1590/S1679-62252005000400006

Ribeiro AC, Melo ALA, Pereira EHL (2002) A new species of Parotocinclus (Siluriformes: Loricariidae) from the rio São Francisco basin, southeastern Brazil. Ichthyological Exploration of Freshwaters 13(3): 217-224.

Roxo FF, Oliveira C, Zawadzki CH (2012) Three new species of Neoplecostomus (Teleostei: Siluriformes: Loricariidae) from the Upper Rio Paraná basin of southeastern Brazil. Zootaxa 3233: 1-21.

Roxo FF, Silva GSC, Oliveira C, Zawadzki CH (2013) Hisonotus bocaiuva, a new species from the rio São Francisco basin, Brazil (Teleostei: Loricariidae). Ichthyological Exploration of Freshwaters 23(4): 319-326.

Roxo FF, Albert JS, Silva GS, Zawadzki CH, Foresti F, Oliveira C (2014a) Molecular Phylogeny and Biogeographic History of the Armored Neotropical Catfish Subfamilies Hypop- 
topomatinae, Neoplecostominae and Otothyrinae (Siluriformes: Loricariidae). PLoS ONE 9(8): e105564. doi: 10.1371/journal.pone.0105564

Roxo FF, Zawadzki CH, Troy WP (2014b) Description of two new species of Hisonotus Eigenmann \& Eigenmann, 1889 (Ostariophysi, Loricariidae) from the rio Paraná-Paraguay basin, Brazil. ZooKeys 395: 57-78. doi: 10.3897/zookeys.395.6910

Sabaj MH, Armbruster JW, Page LM (1999) Spawning in Ancistrus (Siluriformes: Loricariidae) with comments on the evolution of snout tentacles as a novel reproductive strategy: larval mimicry. Ichthyological Exploration of Freshwaters 10(3): 217-229.

Schaefer SA (1998) Conflict and resolution: impact of new taxa on phylogenetic studies of the Neotropical cascudinhos (Siluroidei: Loricariidae). In: Malabarba LR, Reis RE, Vari RP, Lucena ZMS, Lucena CAS (Eds) Phylogeny and classification of neotropical fishes. Edipucrs, Porto Alegre, RS, 375-400.

Silva GSC, Roxo FF, Oliveira C (2014) Hisonotus acuen, a new and phenotypically variable cascudinho (Siluriformes, Loricariidae, Hypoptopomatinae) from the upper rio Xingu basin, Brazil. ZooKeys 442:105-125. doi: 10.3897/zookeys.442.7870

Steindachner F (1877) Die Süsswasserfische des südöstlichen Brasilien. (IV). Sitzungsberichte der Kaiserlichen Akademie der Wissenschaften. Mathematisch-Naturwissenschaftliche Classe 76(1): 217-230.

Taylor WR, Van Dyke GC (1985) Revised procedures for staining and clearing small fishes and other vertebrates for bone and cartilage study. Cybium 9: 107-109.

Tschudi JV (1846) Ichthyologie. ii-xxx+ 1-35, pls. 1-6. Untersuchungen über die Fauna Peruana, Scheitlin \& Zollikofer, 1-693.

Zawadzki CH, Pavanelli CS, Langeani F (2008) Neoplecostomus (Teleostei: Loricariidae) from the upper Rio Paraná basin, Brazil, with description of three new species. Zootaxa 1757: $31-48$.

\section{Electronic references}

Eschmeyer W (2014) Catalog of Fishes. Electronic publication in "World Wide Web". http:// research.calacademy.org/ichthyology/catalog [accessed November 2014]

Eschmeyer WN, Fong JD (2014) Species by Family/Subfamily. http://research.calacademy. org/research/ichthyology/catalog/SpeciesByFamily.asp/ [accessed November 2014]

Fricke R, Eschmeyer WN (2014) Catalog of fishes. http://research.calacademy.org/research/ ichthyology/catalog/collections.asp [accessed November 2014] 